\title{
Effects of long-term protein excess or deficiency on whole-body protein turnover in sheep nourished by intragastric infusion of nutrients
}

\author{
BY S. M. LIU, G. E. LOBLEY, N. A. MACLEOD, D. J. KYLE, X. B. CHEN \\ AND E. R. ØRSKOV \\ Rowett Research Institute, Greenburn Road, Bucksburn, Aberdeen AB2 9SB
}

(Received 14 March 1994 - Revised 26 October 1994 - Accepted 31 October 1994)

\begin{abstract}
The effect of long-term dietary protein excess and deficit on whole-body protein- $\mathrm{N}$ turnover (WBPNT) was examined in lambs nourished by intragastric infusions of nutrients. Ten sheep were given $500 \mathrm{mg} \mathrm{N} / \mathrm{kg}$ metabolic weight $\left(\mathrm{W}^{0.75}\right)$ per $\mathrm{d}$ from casein for 2 weeks and then either $50(\mathrm{~L}), 500(\mathrm{M})$ or $1500(\mathrm{H}) \mathrm{mg} \mathrm{N} / \mathrm{kgW}^{0.75}$ per $\mathrm{d}$ for 6 weeks. Volatile fatty acids were infused at $500 \mathrm{~kJ} / \mathrm{kgW}^{0.75}$ per d. Daily WBPNT was measured by continuous intravenous infusion of $\left[1-{ }^{13} \mathrm{C}\right]$ leucine $3 \mathrm{~d}$ before, and on days 2, 21 and 42 after the alteration in protein intake. Whole-body protein-N synthesis (WBPNS) was calculated as the difference between WBPNT and the protein-N losses as urinary $\mathrm{NH}_{3}$ and urea. Wholebody protein-N degradation (WBPND) was then estimated from WBPNS minus protein gain determined from $\mathbf{N}$ balance. Fractional rates of WBPNS and WBPND were calculated against fleece-free body $\mathbf{N}$ content. WBPNS rates at the $L, M$ and $H$ intakes were respectively $35 \cdot 1,41.5$ amd $63.7 \mathrm{~g} / \mathrm{d}(P<0.001)$ on average over the 6 weeks and WBPND rates were $39.5,41.1$ and $56.8 \mathrm{~g} / \mathrm{d}(P<0.001)$. The fractional rates of WBPNS were $5.01,6.37$ and $7.73 \%$ per $d(P<0.001)$ while those of WBPND were $5.64,6.29$ and $6.81 \%$ per $d(P<0.005)$ respectively. On days 2,21 and 42 , WBPNS rates at intake $H$ were 54.0, 61.8 and $75.4 \mathrm{~g} / \mathrm{d}(P=0.03)$ respectively, and WBPND rates were $43.2,56.4$ and $70.9 \mathrm{~g} / \mathrm{d}(P=0.03)$; at intake $L$ the amounts were $38.2,34.2$ and $32.8 \mathrm{~g} / \mathrm{d}$ for WBPNS $(P=0.003)$ and for WBPND were 43.4, 38.0 and $36.9 \mathrm{~g} / \mathrm{d}(P=0.016)$ respectively. There were no significant $(P>0.05)$ differences in fractional rates of WBPNS and WBPND with time at either the $\mathrm{L}$ or $\mathrm{H}$ intake. We concluded that absolute protein turnover was affected both by dietary protein intake and by body condition while the fractional rate of turnover was predominantly influenced by intake.
\end{abstract}

Whole-body protein turnover: Intragastric nutrient infusion: Sheep

Whole-body protein turnover (WBPT) includes dynamic flows of both endogenous and exogenous substrates and exceeds considerably the net $\mathrm{N}$ balance (NB) or protein gain. Both WBPT and NB vary with dietary intake at any given metabolic and physiological state (Waterlow et al. 1978; Garlick, 1980; Riis, 1983; Lobley, 1993). Whole-body protein synthesis (WBPS) and degradation (WBPD), the constituent processes of WBPT, can vary in similar or opposite directions but usually a high protein intake results in elevated WBPT accompanied by an improved growth rate. Conversely, a low WBPT usually stems from a low intake, with fasting as an extreme. Identifying the influences of both intake and the metabolic state on protein metabolism in ruminants is, however, complicated since experiments involving adaptation to protein over- or under-supply in ruminants have to overcome three concerns. The first, which is exclusive to normally fed ruminants, involves the difficulty in quantifying the actual protein supply because rumen fermentation alters both the quantity and quality of absorbed dietary amino acids. This is overcome by the technique of intragastric infusion which allows control of both energy and amino acid 
supply and at a constant rate, aiding the establishment of a metabolic steady state preferred for protein kinetic studies. The second involves resolution of acute from chronic effects. This is best achieved by within-animal comparisons and use of the non-destructive irreversible loss rate procedure (Reeds \& Lobley, 1980), allowing measurements at different time intervals. The third problem relates to changes in body condition, consequent on the differences in nutrient supply, which possibly have an effect on protein metabolism. Such changes may be assessed, at least for protein mass, by the use of continuous NB and extrapolation data from terminal slaughter.

These approaches were combined in the present study with sheep to examine the effect of both protein intake and body condition on protein metabolism. The energy supply from volatile fatty acids (VFA) was maintained constant while protein infusion was varied to either 3,1 or $0 \cdot 1$ times $\mathrm{N}$ equilibrium over a $42 \mathrm{~d}$ period and changes in NB, WBPS and WBPD were monitored at various intervals.

\section{MATERIALS AND METHODS}

\section{Animals}

Ten Suffolk $\times$ Greyface castrated lambs (initial live weight 36.9 (SD 7.9) $\mathrm{kg}$; this includes one replacement animal of $22 \mathrm{~kg}$ ) of 7 months of age were surgically prepared with a permanent rumen cannula and an abomasal catheter as described previously (Ørskov et al. 1979).

\section{Treatments}

The lambs were housed in metabolism cages. They were nourished completely by intragastric nutrient infusions as described by Orskov et al. (1979) and MacLeod et al. (1982). The mixture of VFA contained acetic acid, propionic acid and butyric acid in the molar proportions of $0 \cdot 65: 0 \cdot 25: 0 \cdot 10$, and was infused initially at approximately $100 \mathrm{~kJ} / \mathrm{kg}$ metabolic weight $\left(\mathrm{W}^{0.75}\right)$ per $\mathrm{d}$ and increased to $500 \mathrm{~kJ} / \mathrm{kgW}^{0.75}$ per $\mathrm{d}$ over a period of $12 \mathrm{~d}$. This infusion was then maintained at a constant rate throughout the experiment. The casein infusion started at a rate of $250 \mathrm{mg} \mathrm{N} / \mathrm{kgW}^{0.75}$ per $\mathrm{d}$ and was increased to $500 \mathrm{mg} \mathrm{N} / \mathrm{kgW}^{0.75}$ per $\mathrm{d}$ over a period of $6 \mathrm{~d}$. These levels of casein and VFA were maintained for 2 weeks (maintenance period). The lambs were then divided into three groups and infused with casein- $\mathrm{N}$ at $1500(\mathrm{H}, n 3), 500(\mathrm{M}, n 3)$ and $50\left(\mathrm{~L}, n 4\right.$; one lamb died at day 35) $\mathrm{mg} / \mathrm{kgW}^{0.75}$ per $d$ respectively for a treatment period of 6 weeks. The amounts of casein infused were calculated according to the initial live body weight and maintained at a constant rate over the period although the live weight did change with time.

\section{Procedures for infusion of $\left[1-{ }^{13} \mathrm{C}\right]$ leucine}

Each sheep was fitted with two polyvinyl catheters in the external jugular veins and maintained as described previously (Lobley et al. 1992). Each lamb was infused with labelled leucine on four occasions: $3 \mathrm{~d}$ before the alteration in protein intake (in the maintenance period) and on days 2, 21 and 42 after alteration of protein intakes. Infusates were prepared with $0 \cdot 3 \mathrm{~g}\left[1-{ }^{13} \mathrm{C}\right]$ leucine (99 atoms \%; Tracer Technologies Inc., Somerville, MA, USA) dissolved in $200 \mathrm{~g}$ sterile saline $(9 \mathrm{~g} \mathrm{NaCl} / 1)$ and infused via the jugular catheter for $8 \mathrm{~h}(20 \mathrm{~g} / \mathrm{h} ; 250 \mu \mathrm{mol}$ leucine $/ \mathrm{h})$.

During each period of leucine infusion a total of six blood samples (each of $5 \mathrm{ml}$ ) was withdrawn into EDTA : one was taken pre-infusion to establish plasma-free leucine natural abundance while the remainder were taken at hourly intervals over the final $4 \mathrm{~h}$ infusion. Plasma was prepared immediately by centrifugation at $3000 \mathrm{~g}$ for $15 \mathrm{~min}$ at $4^{\circ}$ and then stored at $-20^{\circ}$. 
Daily NB measurements were performed throughout (Ørskov \& MacLeod, 1982). Urine samples were stored at $-20^{\circ}$ for analysis of total $\mathrm{N}$, urea and $\mathrm{NH}_{3}$.

\section{Chemical analysis}

$\left[1-{ }^{13} \mathrm{C}\right] 4-$ methyl-2-oxopentanoate (MOP) and $\left[1-{ }^{13} \mathrm{C}\right]$ leucine fractions from $0.7 \mathrm{ml}$ plasma were prepared and analysed for enrichment as described by Calder \& Smith (1988), using a gas chromatography mass spectrometer system (VG TRIO-1; VG MASSLAB Ltd, Manchester, Ches.).

Urine $\mathrm{N}$ was measured by a Kjeldahl procedure (Davidson et al. 1970) while urea and $\mathrm{NH}_{3}$ were measured by modified automated procedures from Marsh et al. (1965) and Fawcett \& Scott (1960) respectively.

Total body $\mathrm{N}$ content was determined at the end of the experiment when the animals were shorn and killed, and the digesta were removed. The fleece-free empty body was minced, weighed, sampled and then freeze-dried. The $\mathrm{N}$ concentrations of the samples were determined by the Kjeldahl procedure. The fleece was dried at $100^{\circ}$ and the $\mathrm{N}$ content calculated by multiplying the dry weight by 0-134 (Agricultural Research Council, 1984), Since the sheep was sheared at the beginning of the experiment, the fleece- $N$ content was considered as the $\mathbf{N}$ retained in wool growth over the experimental period. Daily NB (N intake minus faeces- $N$ and urine- $N$ ) was then adjusted by subtraction of the calculated daily average $\mathrm{N}$ retention in the fleece. The fleece-free body- $\mathrm{N}$ (FFBN) content throughout the experiment was then calculated from extrapolation of the terminal $\mathbf{N}$ content by subtracting the cumulative adjusted NB.

\section{Calculations}

In this experiment the irreversible loss rate (ILR) of free leucine was calculated based on plasma MOP enrichments as representative of the tissue precursor pool (Matthews et al. 1982). The ILR was calculated as follows:

$$
\begin{aligned}
& \operatorname{ILR}(\mathrm{mmol} / \mathrm{h})=\left(\frac{\left[1-{ }^{13} \mathrm{C}\right] \text { leucine enrichment in infusate }}{\left[1-{ }^{13} \mathrm{C}\right] \mathrm{MOP} \text { enrichment in plasma }}-1\right) \\
& \times\left[1-{ }^{13} \mathrm{C}\right] \text { leucine infusion rate }(\mathrm{mmol} / \mathrm{h}) .
\end{aligned}
$$

The ILR was then converted to the $\mathrm{N}$ flux of the whole-body free amino acids (N ILR, $\mathrm{g} / \mathrm{d}$ ) assuming body protein contains $16 \% \mathrm{~N}$ and $6.8 \%$ leucine (Reeds \& Lobley, 1980). The calculation for whole-body protein-N synthesis (WBPNS, g/d) was based on a simplified model (Waterlow et al. 1978) as follows:

$$
\mathrm{N} \text { ILR }=\text { WBPNS }+\mathrm{O}=\mathrm{I}+\mathrm{WBPND},
$$

where $O$ is amino acid-N oxidation and $I$ is dietary amino acid- $N$ intake $(\mathrm{g} / \mathrm{d})$. In the present study $\mathrm{O}$ was assumed as the sum of the daily urinary excretion $(\mathrm{g} / \mathrm{d})$ of urea-N and $\mathrm{NH}_{3}-\mathrm{N}$ (Reeds et al. 1980). Whole-body protein-N degradation (WBPND, g/d) was calculated as the difference between WBPNS and the daily adjusted NB. The fractional rates of N ILR, WBPNS and WBPND were calculated against the corresponding FFBN content.

In such procedures direct measures are not always possible and the current study involved determination of leucine plasma ILR, $\mathrm{NB}$, urinary urea- $\mathrm{N}$ and $\mathrm{NH}_{3}-\mathrm{N}$, and terminal body- $\mathrm{N}$ content. These data were then used to derive N ILR, WBPNS, WBPND and FFBN. Such procedures are widely adopted but care must be exercised that compound errors do not arise. 


\section{Statistical analysis}

To reduce differences between the animals they were all initially maintained at $500 \mathrm{mg} \mathrm{N} / \mathrm{kgW}^{0 \cdot 75}$ per $\mathrm{d}$ for 2 weeks. A treatment (protein intake) effect was calculated as the difference between the average over days 2,21 and 42 and the value at the maintenance period. The treatment effect of each animal was then used in one-way analysis of variance with intake as factor to derive the difference between the three $\mathrm{N}$ intakes. On the other hand, the effect of the body condition was derived by a comparison of the differences between days 2, 21 and 42 at the same intake. Since the comparisons were made within animals, the original values were used directly. Two-way analysis of variance was used with time as factor and animal as a blocking factor. One lamb on the low $\mathrm{N}$ intake died at day 35 so that the results on day 42 were not obtained. The missing values were estimated by Genstat 5 and were included in the means but excluded in variance analyses. All analyses were performed using Genstat 5 (1988).

\section{RESULTS}

At the end of the experiment, live weights of the sheep averaged $44.3,33.3$ and $37.7 \mathrm{~kg}$ for the $H, M$ and $L$ intakes respectively. The changes over the 6 weeks were $+7 \cdot 3,+1 \cdot 3$ and $-2.5 \mathrm{~kg}$ respectively.

\section{$N I L R$, protein synthesis and degradation}

ILR of $\mathrm{N}$, urinary urea-N and $\mathrm{NH}_{3}-\mathrm{N}$, WBPNS, WBPND and adjusted NB are shown in Table 1. During the maintenance period all these variables were similar for all animals.

Responses to alteration in $\mathrm{N}$ intake were rapid and persistent. Average $\mathrm{N}$ ILR values were $78.0,46.0$ and $37.8 \mathrm{~g} / \mathrm{d}$ for $\mathrm{H}, \mathrm{M}$ and $\mathrm{L}$ intakes respectively. The urinary urea- $\mathrm{N}$ plus $\mathrm{NH}_{3}-\mathrm{N}$ excretions were $14 \cdot 2,4 \cdot 5$ and $2 \cdot 7 \mathrm{~g} / \mathrm{d}$. Calculated WBPNS rates were $63 \cdot 7,41 \cdot 5$ and $35.1 \mathrm{~g} / \mathrm{d}$ and WBPND rates were $56 \cdot 8,41 \cdot 1$ and $39.5 \mathrm{~g} / \mathrm{d}$, while daily NB values were 6.9, 0.5 and $-4.4 \mathrm{~g} / \mathrm{d}$ respectively. The average changes after alteration in $\mathrm{N}$ intake are listed in Table 3. The differences were all significant $(P<0.001)$ between intakes.

N ILR, WBPNS and WBPND at either the high or the low intake were significantly different between days 2,21 and 42 , indicating the persistent effect of long-term protein excess or deficit on protein metabolism.

At the higher intake when compared with the maintenance period the daily $\mathrm{N}$ ILR increased by $51 \%$, WBPNS by $36 \%$ and WBPND by $20 \%$. The converse occurred for the low-protein animals: N ILR decreased by $32 \%$, WBPNS by $30 \%$ and WBPND by $21 \%$.

\section{Fractional rates of $N I L R, W B P N S$ and $W B P N D$}

Total FFBN content, fractional rates of N ILR, WBPNS and WBPND are shown in Table 2 and the average differences in values between the treatment and maintenance periods are listed in Table 3. The fractional rates of N ILR at the $H, M$ and $L ~ N$ intakes averaged 9.42, 7.04 and $5.39 \%$ per $d$ respectively over the 6 weeks. The fractional synthesis rates (WBPNS) were $7.73,6.37$ and $5.01 \%$ per $\mathrm{d}$, and the fractional degradation rates (WBPND) were 6.81, 6.29 and $5.64 \%$ per d respectively. Dietary $N$ intake significantly influenced the fractional rates of N ILR $(P<0.001)$ and WBPNS $(P<0.005)$ but not of WBPND $(P>0.1)$. On average, raising $\mathrm{N}$ intake from the initial $500 \mathrm{mg} / \mathrm{kgW}^{0.75}$ per $\mathrm{d}$ to treatment $\mathrm{H}$ induced increases in the fractional rate of N ILR of $27 \%$, WBPNS of $14 \%$ and WBPND of $0.2 \%$, while a decrease of $\mathrm{N}$ intake from the initial $500 \mathrm{mg} / \mathrm{kgW}^{0.75}$ per $\mathrm{d}$ to treatment $\mathrm{L}$ resulted in reductions of 22,21 and $11 \%$ respectively. Thus, change in WBPND between the $L$ and $\mathrm{H} \mathrm{N}$ intakes was $11 \%$, approximately one third of the alteration in WBPNS. 
Table 1. Whole-body amino acid-N irreversible loss rate ( $N$ ILR), protein- $N$ synthesis (WBPNS) and degradation (WBPND), and nitrogen balance (NB) in sheep infused with different amounts of casein and with $500 \mathrm{~kJ} / \mathrm{kg}$ metabolic weight $\left(W^{0.75}\right)$ per d of volatile fatty acids for 6 weeks*

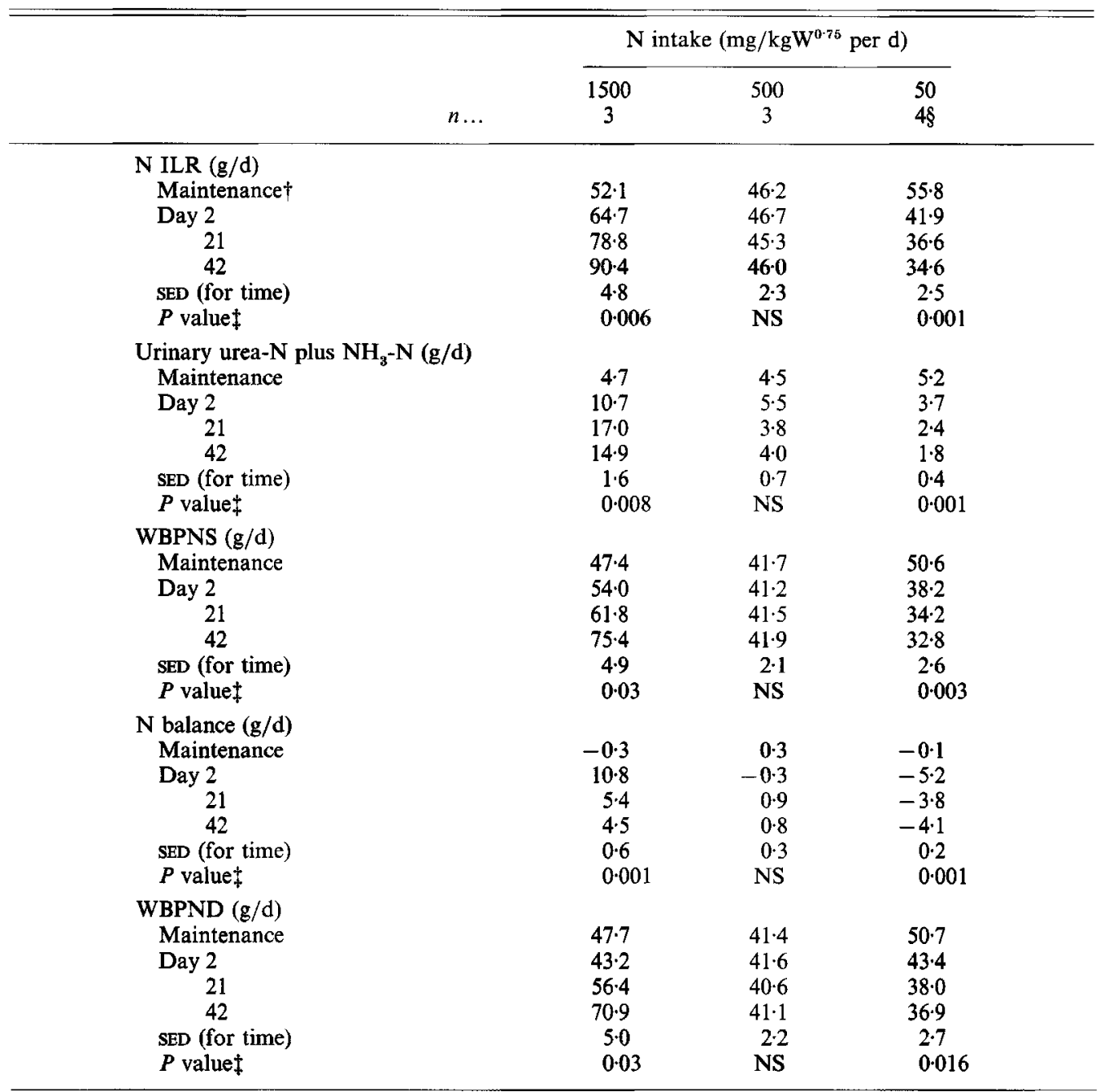

* For details of procedures, see pp. 830-832.

$\uparrow$ The maintenance period ( $500 \mathrm{mg} \mathrm{N} / \mathrm{kgW}^{0.75}$ per $\mathrm{d}$ for all animals). None of the variables was significantly different.

\$ The effect of duration of time at the same $\mathrm{N}$ intake. The residual degrees of freedom were 6,6 and 7 on the high, medium and low $\mathrm{N}$ intakes respectively.

$\S$ See statistical analysis, p. 832 . 
Table 2. Fleece-free body-N (FFBN) content, fractional rates of amino acid- $N$ irreversible loss rate (NILR), protein-N synthesis (WBPNS) and degradation (WBPND) in sheep infused with different amounts of casein and with $500 \mathrm{~kJ} / \mathrm{kg}$ metabolic weight $\left(W^{0 \cdot 75}\right)$ per d of volatile fatty acids for 6 weeks*

\begin{tabular}{|c|c|c|c|}
\hline & \multicolumn{3}{|c|}{$\mathrm{N}$ intake $\left(\mathrm{mg} / \mathrm{kgW}^{0.75}\right.$ per $\left.\mathrm{d}\right)$} \\
\hline & 1500 & 500 & 50 \\
\hline \multicolumn{4}{|c|}{ FFBN content $(\mathrm{g}) \dagger$} \\
\hline Maintenance & 705 & 641 & 802 \\
\hline Day 2 & 716 & 642 & 796 \\
\hline 21 & 845 & 653 & 709 \\
\hline 42 & 931 & 670 & 639 \\
\hline SED (for time) & 12 & 3 & 4 \\
\hline$P$ valuet & 0.001 & NS & 0.001 \\
\hline \multicolumn{4}{|l|}{ N ILR $(\%$ per $d)$} \\
\hline Maintenance & 7.44 & $7 \cdot 22$ & 7.02 \\
\hline Day 2 & $9 \cdot 19$ & $7 \cdot 27$ & $5 \cdot 34$ \\
\hline 21 & $9 \cdot 36$ & 6.98 & $5 \cdot 32$ \\
\hline 42 & 9.72 & 6.87 & $5 \cdot 50$ \\
\hline SED (for time) & 0.72 & 0.33 & 0.35 \\
\hline$P$ valuef & NS & NS & NS \\
\hline \multicolumn{4}{|c|}{ WBPNS ( $\%$ per $d)$} \\
\hline Maintenance & 6.77 & 6.51 & $6 \cdot 37$ \\
\hline Day 2 & 7.66 & 6.43 & $4 \cdot 86$ \\
\hline 21 & 7.39 & $6 \cdot 40$ & 4.99 \\
\hline 42 & $8 \cdot 13$ & $6 \cdot 28$ & $5 \cdot 19$ \\
\hline SED (for time) & 0.70 & 0.23 & $0 \cdot 34$ \\
\hline$P$ value & NS & NS & NS \\
\hline \multicolumn{4}{|c|}{ WBPND (\% per d) } \\
\hline Maintenance & 6.82 & $6 \cdot 46$ & $6 \cdot 39$ \\
\hline Day 2 & 6.08 & $6 \cdot 47$ & $5 \cdot 55$ \\
\hline 21 & 6.73 & $6 \cdot 26$ & $5 \cdot 57$ \\
\hline 42 & $7 \cdot 63$ & $6 \cdot 15$ & $5 \cdot 81$ \\
\hline SED (for time) & 0.70 & $0 \cdot 28$ & 0.36 \\
\hline$P$ valuet & NS & NS & NS \\
\hline
\end{tabular}

* For details of procedures, see pp. 830-832.

$\dagger$ FFBN content on day 42 was measured and the remainder were extrapolated from the $42 \mathrm{~d}$ content and cumulative $\mathrm{N}$ balance.

+ The effect of duration of time at the same $N$ intake. The residual degrees of freedom were 6,6 and 7 on the high, medium and low $\mathrm{N}$ intakes respectively.

After alteration to the $\mathrm{H}$ or $\mathrm{L}$ intake there were no significant differences $(P>0.05)$ in any of the fractional rates between days 2,21 and 42 .

\section{Contributions to N ILR and protein synthesis}

The ILR of leucine consists of the amino acids ingested from the diet (exogenous) and those degraded from body protein (endogenous); the latter can be estimated from the difference between flux and intake (infused casein). During the maintenance period the exogenous $\mathrm{N}$ supply was $7.0 \mathrm{~g} / \mathrm{d}$ while the corresponding $\mathrm{N}$ ILR was $51.8 \mathrm{~g} / \mathrm{d}$. The endogenous contribution was thus $44.8 \mathrm{~g} / \mathrm{d}$ or $86 \% \mathrm{~N}$ ILR. On day 2 after alteration to the $\mathrm{H}$ intake the exogenous supply was $22 \cdot 1 \mathrm{~g} / \mathrm{d}$ while the endogenous was $42.6 \mathrm{~g} / \mathrm{d}$ or $66 \% \mathrm{~N}$ ILR. At the $\mathrm{L}$ intake the values were $0.8 \mathrm{~g} / \mathrm{d}$ (exogenous) and $41.2 \mathrm{~g} / \mathrm{d}$ (endogenous, $98 \% \mathrm{~N} \mathrm{ILR}$ ) respectively. The quantities of the endogenous contributions were not significantly different 
Table 3. Treatment ( $N$ intake) effects calculated as the average over days 2, 21 and 42 minus the value at the maintenance period*

\begin{tabular}{|c|c|c|c|c|c|}
\hline & \multicolumn{3}{|c|}{$\mathrm{N}$ intake $\left(\mathrm{mg} / \mathrm{kgW}^{0.75}\right.$ per $\left.\mathrm{d}\right)$} & \multirow[b]{2}{*}{ SED } & \multirow[b]{2}{*}{$P$ value $\dagger$} \\
\hline & 1500 & 500 & 50 & & \\
\hline$N \operatorname{ILR}(\mathrm{g} / \mathrm{d})$ & $25 \cdot 9$ & $-0 \cdot 2$ & $-18 \cdot 0$ & $3 \cdot 3$ & $<0.001$ \\
\hline Urinary urea-N plus $\mathrm{NH}_{3}-\mathrm{N}(\mathrm{g} / \mathrm{d})$ & $9 \cdot 5$ & $-0 \cdot 1$ & $-2 \cdot 6$ & $1 \cdot 3$ & $<0.001$ \\
\hline WBPNS $(\mathrm{g} / \mathrm{d})$ & $16 \cdot 3$ & $-0 \cdot 1$ & $-15 \cdot 5$ & 3.9 & $<0.001$ \\
\hline $\mathrm{N}$ balance $(\mathrm{g} / \mathrm{d})$ & $7 \cdot 2$ & 0.2 & $-4 \cdot 3$ & 0.8 & $<0.001$ \\
\hline WBPND $(g / d)$ & $9 \cdot 1$ & $-0 \cdot 3$ & $-11 \cdot 2$ & $3 \cdot 8$ & $<0.005$ \\
\hline FFBN content $(g)$ & $125 \cdot 8$ & $14 \cdot 2$ & $-86 \cdot 8$ & $10 \cdot 9$ & $<0.001$ \\
\hline $\mathrm{N} \operatorname{ILR}(\%$ per $\mathrm{d})$ & $2 \cdot 0$ & -0.2 & -1.6 & 0.5 & $<0.001$ \\
\hline WBPNS $(\%$ per $d)$ & $1 \cdot 0$ & $-0 \cdot 1$ & $-1 \cdot 4$ & 0.5 & $<0.005$ \\
\hline WBPND (\% per d) & -0.01 & -0.2 & -0.8 & 0.5 & $>0.1$ \\
\hline
\end{tabular}

N ILR, whole-body amino acid-N irreversible loss rate; WBPNS, whole-body protein-N synthesis; WBPND, whole-body protein-N degradation; FFBN, fleece-free body-N, $\mathrm{W}^{\mathbf{0} 75}$, metabolic weight.

* For details of experimental protocol, see pp. 830-832.

$\dagger$ The residual degree of freedom was 7 .

from that at maintenance, although N ILR changed in proportion to the intakes. From days 2 to 42 , however, either a progressive increase $(P=0.006)$ or a decrease $(P<0.001)$ in N ILR dependent on N intake was observed (Table 1) and, because the exogenous intake was constant, time-related changes in the endogenous contribution must therefore have occurred.

During the maintenance period the proportion of N ILR from synthesis was 0.91 (SE 0.01) but after the alteration in $\mathrm{N}$ intake, the contributions were $0.82,0.89$ and 0.93 at the $\mathrm{H}, \mathrm{M}$ and $\mathrm{L} \mathrm{N}$ intakes respectively. Differences between the treatments were significant $(P<0.001)$ but independent of time.

\section{$N$ retention and protein synthesis}

The average daily NB and corresponding protein- $\mathrm{N}$ synthesis values were significantly and positively correlated $(r 0.725, n 38, P<0.001)$. The slope was 0.313 (SE $0.05, P<0.001) \mathrm{g} \mathrm{N}$ retained/g protein- $\mathrm{N}$ synthesized.

\section{DISCUSSION \\ Effect of protein intakes}

The effects of dietary protein intakes on whole-body protein metabolism of the sheep in the present experiment agree with other published reports. The average changes from the $N$ intake of $500 \mathrm{mg} / \mathrm{kgW}^{0.75}$ per $\mathrm{d}$ in the maintenance period to $1500 \mathrm{mg} / \mathrm{kgW}^{0.75}$ per d were $+36 \%$ in protein synthesis and $+20 \%$ in degradation. Changes in synthesis and degradation between the maintenance intake and the low $\mathrm{N}$ intake of $50 \mathrm{mg} / \mathrm{kgW}^{0.75}$ per $\mathrm{d}$ were -30 and $-21 \%$ respectively. The effect of $\mathrm{N}$ intake on protein synthesis was thus greater than the effect on degradation. This was also observed in growing young sheep fed on $0.6,1.2$ and $1.8 \times$ energy maintenance $(M)$ diets where protein synthesis and degradation increased by 25 and $18 \%$ between $1.2 \times \mathrm{M}$ and $1.8 \times \mathrm{M}$, but decreased by 25 and $16 \%$ respectively from $1.2 \times \mathrm{M}$ to $0.6 \times \mathrm{M}$ (Harris et al. 1992). In steers reduced from maintenance to fasting, protein synthesis decreased by $18 \%$ and protein degradation by $2 \%$; while between maintenance and $1.6 \times \mathrm{M}$ protein synthesis and degradation increased 
by 26 and $20 \%$ respectively (Lobley et al. 1987). Thus, overall response of degradation to a change in dietary protein intake is smaller than that of synthesis.

\section{Acute responses to dietary protein changes}

Marked acute responses in protein synthesis and degradation were observed on day 2 after alteration in intakes although they were not statistically different from the maintenance because of large individual variation, indicative of a rapid adjustment in metabolism to exogenous protein intake. The reaction to excess protein involved a stimulation of synthesis and inhibition of degradation (Table 1). A similar suppression has been observed in rat tissues. For example, inhibition of liver protein degradation measured by the decay of $\mathrm{NaH}^{14} \mathrm{CO}_{3}$ was found during the first few days of regeneration in partly hepatectomized rats (Swick \& Ie, 1974; Scornik \& Bothol, 1976), and immediately after feeding (Garlick, 1980). Rapid regrowth of muscle protein was accompanied by a substantial suppression of protein breakdown (Young et al. 1971). In contrast, when the sheep were switched from maintenance to low protein status there were immediate declines in total protein flux and in both synthesis and degradation, and because the fractional rates established by day 2 were similar to those on days 21 and 42 the adjustment was thus both rapid and substantial. This was also reflected in urinary total-N excretion which fell by $20 \%$ on the first day of intake reduction but then declined more slowly and by a similar absolute percentage over the following $41 \mathrm{~d}$.

The differences in fractional synthesis rates between the excess and deficit protein intakes may represent similar changes in the turnover of all body tissues; alternatively, some organs may be more responsive than others. The latter option is more probable because for sheep the peripheral tissues, skin and skeletal muscle, exhibit marked changes in fractional synthesis rate in response to overall changes in dietary status (Oddy et al. 1987; Lobley et al. 1992; see Lobley, 1993) whereas liver and the gastrointestinal tract are affected only slightly (Lobley et al. 1994).

\section{Effects of long-term protein excess and deficiency}

Time-related increases and decreases in daily absolute protein turnover in the lambs were observed for the high and the low $\mathbf{N}$ intakes. Since the $\mathbf{N}$ intakes were constant these changes could only arise from altered endogenous contributions, i.e. body protein degradation. However, neither WBPNS (\% per d) nor WBPND ( $\%$ per d), changed significantly with time, indicating that the rate of protein metabolism per unit of protein mass, once established within the first $2 \mathrm{~d}$ of resetting the intakes, was not altered. Therefore, the time-related changes in turnover, and in turn synthesis and degradation, must have occurred predominantly from changes in body-protein mass since the synthesis:turnover ratio was also time-independent. In fact, the body-protein mass was enlarged by $34 \%$ or diminished by $21 \%$ over the 6 weeks as the consequence of constant excess or deficit in protein intake. A close relationship between the increased body protein content and the leucine flux was observed in growing lambs on a normal diet with or without casein infusion (Davis et al. 1981). Body condition also affected protein turnover in children, before and after recovery from malnutrition states. During malnutrition a lower rate of protein turnover $(\mathrm{g} / \mathrm{kg}$ live weight per $\mathrm{d})$ was observed compared with that after the recovery even at comparable intakes (Waterlow et al. 1977).

\section{Partition of precursors between synthesis and oxidation}

In tie simplified model described in the calculation, amino acid turnover is partitioned between protein synthesis and oxidation, and this partition adjusts to different nutritional conditions. In the present experiment the changes in N ILR, WBPNS and urea-N plus 
$\mathrm{NH}_{3}-\mathrm{N}$ were $-32,-30$ and $-48 \%$ when $\mathrm{N}$ intake was altered from $500 \mathrm{mg} / \mathrm{kgW}^{0.75}$ per $\mathrm{d}$ to $50 \mathrm{mg} / \mathrm{kgW}^{0.75}$ per $\mathrm{d}$; the corresponding values when $\mathrm{N}$ intake was raised to $1500 \mathrm{mg} / \mathrm{kgW}^{0.75}$ per $\mathrm{d}$ were +51 , +36 and $+201 \%$ respectively. Greater changes in oxidation compared with synthesis, particularly on a high $\mathrm{N}$ intake, were therefore observed. This is also reported in other studies. For example, the increments in leucine oxidation and protein synthesis in sheep offered either $0.6 \times$ or $1.8 \times$ maintenance energy diets were 190 and $71 \%$ respectively (Harris et al. 1992). In heifers fed at either $1.2 \times$ or $2.4 \times$ maintenance energy, leucine oxidation and protein synthesis increased by 88 and $58 \%$ respectively (Hammond et al. 1987). Differential sensitivities are also shown in response to altered protein level; for example, in growing pigs fed on diets containing 150 and $290 \mathrm{~g}$ crude protein $/ \mathrm{kg}$, leucine oxidation and protein synthesis changed by +111 and $+11 \%$ respectively (Fuller et al. 1987), while in obese human subjects maintained on a protein-free diet for 3 weeks leucine oxidation and protein synthesis decreased by 83 and $39 \%$ respectively (Garlick et al. 1980). Regulation of amino acid oxidation provides a major mechanism by which animals adapt to different dietary nutrient intakes, i.e. output adjusts to input (Waterlow et al. 1978).

It is not well understood how the partition of amino acids between synthesis and oxidation is controlled by the body. Protein synthesis is universal for all tissues but the major catabolic site for most amino acids is the liver, with the notable exception of the branched-chain amino acids (see Harris \& Lobley, 1991). Oxidation is probably associated with substrate concentration (Waterlow et al. 1978; Lindsay, 1980; Motil et al. 1981; Nissen \& Ostaszewski, 1985; Hammond et al. 1987) and enzymes regulating the catabolism of amino acids have Michaelis constants $\left(K_{\mathrm{m}}\right)$ in the millimolar range while for enzymes initiating protein synthesis (e.g. t-RNA synthetases) the values are in the micromolar range. Thus at low concentration a greater proportion of amino acids will react with the synthetases. As the synthetic pathway of protein becomes saturated and amino acid concentrations increase, the catabolic pathway will assume greater importance (see Lindsay, 1980). Since the $K_{\mathrm{m}}$ of many of the amino acid transaminases (the usual first step in amino acid catabolism) is greater than the amino acid concentrations in vivo, these enzymes are sensitive to increased amino acid concentrations and hence oxidation is stimulated (see Waterlow et al. 1978). With a low protein intake or amino acid input the plasma (and tissue) concentrations of amino acids often remain low, and so does the oxidation of labelled amino acids (Motil et al. 1981; Fuller et al. 1987). With intakes in excess of the maintenance requirement the concentrations increase sharply and the increased enzyme activity results in an increased rate of oxidation.

\section{CONCLUSION}

Overall, the results of the experiment suggested that daily protein turnover, synthesis and degradation during long-term protein excess or deficiency were affected by both dietary protein intake and body protein condition, i.e. body protein mass. At constant dietary intakes the rate of protein turnover per unit of body-protein mass was rapidly established, with the values mainly determined by dietary intake.

The authors gratefully acknowledge the expertise of the Animal Welfare Department for care of the animals, Miss A. Connell for isotopic infusion, Mr D. J. Calder and Mr D. J. Ewing for mass spectrometric analysis, Miss A. Annand and Miss H. M. Addison for analysis of urinary urea and ammonia, Mr K. Pennie for carcass dissection, Mr R. I. Smart for analysis of urine-N and carcass composition, Mr M. Franklin for statistical analysis of data and $\mathrm{Mr}$ W. J. Shand for overall experimental support. S. M. Liu is a recipient of a 
post-graduate award from the Sino-British Friendship Scholarship Scheme. This work was supported by the Scottish Office Agriculture and Fisheries Department.

\section{REFERENCES}

Agricultural Research Council (1984). The Nutrient Requirements of Ruminant Livestock, p. 49. Slough: Commonwealth Agricultural Bureaux.

Calder, A. G. \& Smith, A. (1988). Stable isotope ratio analysis of leucine and ketoisocaproic acid in blood plasma by gas chromatography/mass spectrometry. Use of tertiary butyldimethylsilyl derivatives. Rapid Communications in Mass Spectrometry 2, 14-16.

Davidson, J., Mathieson, J. \& Boyne, A. W. (1970). The use of automation in determining nitrogen by the Kjeldahl method, with final calculations by computer. Analyst 95, 181-193.

Davis, S. R., Barry, T. N. \& Hughson, G. A. (1981). Protein synthesis in tissues of growing lambs. British Journal of Nutrition 44, 129-140.

Fawcett, J. K. \& Scott, J. E. (1960). Rapid and precise method for the determination of urea. Journal of Clinical Pathology 13, 156-159.

Fuller, M. F., Reeds, P. J., Cadenhead, A. \& Seve, B. (1987). Effects of the amount of quality of dietary protein on nitrogen metabolism and protein turnover of pigs. British Journal of Nutrition 58, 287-300.

Garlick, P. J. (1980). Protein turnover in the whole animal and specific tissues. In Comprehensive Biochemistry - Protein Metabolism, vol. 19B, pp. 77-154 [P. J. Garlick and D. J. Millward, editors]. Amsterdam: Elsevier.

Garlick, P. J., Graeme, A. C. \& Waterlow, J. C. (1980). Influence of low-energy diets on whole-body protein turnover in obese subjects. American Journal of Physiology 238, E235-E244.

Genstat 5. Release 2.2. (1988). Reference Manual. Rothamsted Experimental Station, Lawes Agricultural Trust. Oxford: Oxford Science Publications.

Hammond, A. G., Huntington, G. B., Reytnolds, P. J., Tyrrell, H. F. \& Eisemann, J. H. (1987). Absorption, plasma flux and oxidation of L-leucine in heifers at two levels of intake. Journal of Animal Science 64, 420-425.

Harris, P. M. \& Lobley, G. E. (1991). Amino acid and energy metabolism in the peripheral tissues of ruminants. In Physiological Aspects of Digestion and Metabolism in Ruminants: Proceedings of the Seventh International Symposium on Ruminant Physiology, pp. 201-230 [T. Tsude, Y. Sasaki \& R. Kawashima, editors]. San Diego: Academic Press.

Harris, P. M., Skene, P. A., Buchan, V., Milne, E., Calder, A. G., Anderson, S. E., Connell, A. \& Lobley, G. E. (1992). Effect of food intake on hind-limb and whole-body protein metabolism in young growing sheep: chronic studies based on arterio-venous techniques. British Journal of Nutrition 68, 389-407.

Lindsay, D. B. (1980). Amino acids as energy source. Proceedings of the Nutrition Society 39, 53-59.

Lobley, G. E. (1993). Protein metabolism and turnover. In Quantitative Aspects of Ruminant Digestion and Metabolism, pp. 313-339 [J. M. Forbes and J. France, editors]. London: C.A.B. International.

Lobley, G. E., Connell, A. \& Buchan, V. (1987). Effect of food intake on protein and energy metabolism in finishing beef steers. British Journal of Nutrition 57, 457-465.

Lobley, G. E., Connell, A., Milne, E., Newman, A. M. \& Ewing, T. A. (1994). Protein synthesis in splanchnic tissues of sheep offered two levels of intake. British Journal of Nutrition 71, 3-12.

Lobley, G. E., Harris, P. M., Skene, P. A., Brown, D., Milne, E., Calder, A. G., Anderson, S. E., Garlick, P. J., Nevison, I. \& Connell, A. (1992). Responses in tissue synthesis to sub- and supra-maintenance intake in young growing sheep: comparison of large-dose and continuous-infusion techniques. British Journal of Nutrition $\mathbf{6 8}$, 373-388.

MacLeod, N. A., Corrigall, W., Stirton, R. A. \& Ørskov, E. R. (1982). Intragastric infusion of nutrients in cattle. British Journal of Nutrition 47, 547-552.

Marsh, W. H., Fingerhut, B. \& Miller, H. (1965). Automated and manual direct methods for the determination of blood urea. Clinical Chemistry 11, 624-627.

Matthews, D. E., Schwarz, H. P., Yang, R. D., Motil, K. J., Young, V. R. \& Bier, D. M. (1982). Relationship of plasma leucine and $\alpha$-ketoisocaproate during a $\mathrm{L}-\left[1^{13} \mathrm{C}\right]$ leucine infusion in man: a method for measuring human intracellular leucine tracer enrichment. Metabolism 31, 1105-1112.

Motil, K. J., Matthews, D. E., Bier, D. M., Burke, J. F., Munro, H. N. \& Young, V. R. (1981). Whole-body leucine and lysine metabolism: response to dietary protein intake in young men. American Journal of Physiology 240, E712-E721.

Nissen, S. \& Ostaszewski, P. (1985). Effects of supplemental energy on leucine metabolism in sheep. British Journal of Nutrition 54, 705-712.

Oddy, V. H., Lindsay, D. B., Barker, P. J. \& Northrop, A. J. (1987). Effect of insulin on hind-limb and whole body leucine and protein metabolism in fed and fasted lambs. British Journal of Nutrition 55, 143-154.

Ørskov, E. R., Grubb, D. A., Wenham, W. \& Corrigall, W. (1979). The sustenance of growing and fattening ruminants by intragastric infusion of volatile fatty acids and protein. British Journal of Nutrition 41, 553-558.

Ørskov, E. R. \& MacLeod, N. A. (1982). The determination of the minimal nitrogen excretion in steers and dairy cows and its physiological and practical implications. British Journal of Nutrition 47, 625-636. 
Reeds, P. J., Cadenhead, A., Fuller, M. F., Lobley, G. E. \& McDonal, J. D. (1980). Protein turnover in growing pigs. Effect of age and food intake. British Journal of Nutrition 43, 445-455.

Reeds, P. J. \& Lobley, G. E. (1980). Protein synthesis: are there real special differences? Proceedings of the Nutrition Society 39, 43-52.

Riis, P. M. (1983). The pools of tissue constituents and products: proteins. In Dynamic Biochemistry of Animal Production, pp. 75-108 [P. M. Riis, editor]. Amsterdam: Elsevier.

Scornik, O. A. \& Bothol, V. (1976). Role of changes in protein degradation in the growth of regenerating liver. Journal of Biological Chemistry 251, 2891-2897.

Swick, R. W. \& Ie, M. M. (1974). Measurement of protein turnover in rat liver with ${ }^{14}$ C-carbonate. Journal of Biological Chemistry 249, 6836-6841.

Waterlow, J. C., Garlick, P. J. \& Millward, D. J. (1978). Protein Turnover in Mammalian Tissues and in Wholebody. Amsterdam: North-Holland Publishing Company.

Waterlow, J. C., Golden, M. H. N. \& Picou, D. (1977). The measurement of rates of protein turnover, synthesis, and breakdown in man and the effects of nutrition status and surgical injury. American Journal of Clinical Nutrition 30, 1333-1339.

Young, V. R., Stothers, S. C. \& Vilaire, G. (1971). Synthesis and degradation of mixed proteins, and composition changes in skeletal muscle of malnourished and refed rats. Journal of Nutrition 101, 1379-1390. 